\title{
BIOCHEMICAL AND BIOLOGICAL PROPERTIES OF Lonomia obliqua BRISTLE EXTRACT
}

\section{CHUDZINSKI-TAVASSI A. M.(1), CARRIJO-CARVALHO L. C.(1)}

(1) Laboratory of Biochemistry and Biophysics, Butantan Institute, São Paulo, Brazil

ABSTRACT: Lonomia obliqua caterpillar is frequently seen in accidents with humans especially in the south of Brazil. Patients develop a hemorrhagic syndrome that can be treated with specific antilonomic serum. A consumptive coagulopathy was found to be the main cause of bleeding complications observed in patients after contact with $L$. obliqua. Studies revealed that $L$. obliqua caterpillar bristle extract (LOCBE) displays a procoagulant activity that leads to intravascular thrombin formation, resulting in a special form of disseminated intravascular coagulation (DIC). Fibrinolysis seems to be secondary to the fibrin production, since no direct fibrinolytic activity was found in LOCBE. Two procoagulant toxins, a factor $X$ activator (Losac) and a prothrombin activator (Lopap), were isolated from LOCBE and characterized. Infusion of Lopap into experimental animals triggered a condition similar to that observed in human envenomation.

KEY WORDS: Lonomia obliqua, Lonomia obliqua bristle extract, hemorrhagic syndrome, disseminated intravascular coagulation.

\section{CORRESPONDENCE TO:}

ANA MARISA CHUDZINSKI-TAVASSI, Laboratório de Bioquímica e Biofísica, Instituto Butantan, Avenida Vital Brasil, 1500, 05503-900, São Paulo, SP, Brasil. Phone: +55 (11) 37267222 ext. 2109. Fax: +55 (11) 3726 1024. Email: amchudzinski@butantan.gov.br. 
A. M. Chudzinski-Tavassi and L. C. Carrijo-Carvalho BIOCHEMICAL AND BIOLOGICAL PROPERTIES OF Lonomia obliqua BRISTLE EXTRACT. J. Venom. Anim. Toxins incl. Trop. Dis., 2006, 12, 2, p. 157

\section{INTRODUCTION}

Lonomia obliqua is a moth of the Saturniidae family (Lepidoptera), which is called caterpillar at its larval stages with poisonous spines (33). It occurs during spring and summer, especially in the southern part of Brazil. Caterpillars have gregarious habit, live in colonies on trunks or branches of fructiferous trees, and present mimetic characteristics. Human envenomation occurs after accidental contact with the caterpillar bristles, which deliver toxic substances into the victim's skin. The accident is denominated lonomism and may be severe, resulting in a hemorrhagic syndrome characterized by consumptive coagulopathy. Since 1989, a high incidence of accidents by $L$. obliqua has been reported in the southern region of Brazil $(13,20-22$, 29) and therefore it has been considered an important public health problem (18).

The first report of a human accident caused by Lonomia dates from the early 1900 s and describes a hemorrhagic syndrome in a patient who had been in contact with a group of caterpillars (1). However, more detailed studies started around 1960 in Venezuela by Arocha-Piñango and collaborators (2). Since then, various cases of envenomation by Lonomia achelous in Venezuela have been reported and studies with its hemolymph have been carried out $(3-8,27)$.

Lemaire distinguished Lonomia obliqua (Walker) of the south of Brazil from those caterpillars of Venezuela and classified it as Lonomia achelous (Cramer) (30). Although envenomation by $L$. obliqua and $L$. achelous is followed by similar symptoms associated with a hemorrhagic syndrome, these species may differ in their venom properties and mechanism of action. Lonomia achelous presents toxins with fibrinolytic and procoagulant activities (6), and the toxic action of L. obliqua is characterized by a predominant procoagulant activity $(19,38)$. We conducted several in vivo and in vitro studies with LOCBE and two toxins were identified and characterized so far. In this paper, we present a review of the information available up until now about the toxic properties of $L$. obliqua bristle extract and discuss the clinical aspects of envenomation.

\section{HUMAN ACCIDENTS}

Since 1989 L. obliqua has been associated with human accidents in the southern region of Brazil (Rio Grande do Sul, Santa Catarina, and Paraná States), where it is considered epidemic $(18,20,29)$. Nevertheless, this species has overspread from its 
A. M. Chudzinski-Tavassi and L. C. Carrijo-Carvalho BIOCHEMICAL AND BIOLOGICAL PROPERTIES OF Lonomia obliqua BRISTLE EXTRACT. J. Venom. Anim. Toxins incl. Trop. Dis., 2006, 12, 2, p. 158

original places and, recently, new accidental cases were reported in the states of São Paulo (22), Rio de Janeiro (16) and Minas Gerais.

The clinical symptoms of envenomation by $L$. obliqua are very similar to those observed after L. achelous envenomation in Venezuela (5). Severity generally depends on the number of larvae, larval stage, and extension of the patient's skin area involved in the accident $(18,48)$. Initial symptoms are pain, burning sensation, hyperemia, occasional local inflammation at the contact sites, edema, headache, nausea, and vomiting $(14,21,29,53)$. These symptoms are generally followed by systemic reactions associated with a severe coagulopathy and bleeding manifestations. The diagnosis proposed for $L$. obliqua envenomation is characterized by subcutaneous and generalized hemorrhage, including skin, mucosal and visceral bleeding, hematoma, hematuria, gengivorrhagia, ecchymosis, epistaxis, hematemesis, and melena $(14,16,29,53)$. This syndrome usually occurs during the first 12 hours after envenomation and bleeding may appear spontaneously or as a result of mild injuries $(22,53)$. Major complications such as acute renal failure $(13$, 20) and intracerebral bleeding may occur leading the patient to death. Renal failure is relatively frequent among patients envenomed by $L$. obliqua, but it is rarely observed in envenomation by $L$. achelous $(6,13,20)$. Pathogenesis of this manifestation remains unclear, but it may probably be a result from the deposition of fibrin in glomeruli and renal ischemia (22).

Recently, we have published a study that evaluated coagulation and fibrinolysis in 105 patients after contact with $L$. obliqua (53). It is the unique clinical report that concerns a large number of patients affected by $L$. obliqua envenomation. The other few clinical studies available in literature involve only a limited number of envenomed patients $(16,22,29)$ but agree with our findings. In general, patients presented prolonged global coagulation, prothrombin time (PT), activated partial thromboplastin time (APTT), and thrombin time (TT). Fibrinogen $(\mathrm{Fg})$ was reduced in the majority of envenomed patients, and the extent of defibrinogenation was directly associated with bleeding manifestations. Therefore, Fg level could be used as an efficient marker for evaluating the envenomation severity and for monitoring the treatment. A significant decrease in the levels of factors V, XIII and VIII, prekallikrein (PK), and protein C was also observed when fibrinogen was depleted. No changes were observed in factors X, II and von Willebrand Factor (VWF), protein S, and antithrombin (AT). Platelet count remained normal in most cases. A little change observed in the platelet count 
and in the AT level suggests that a different form of clotting activation may be involved in the hemorrhagic syndrome triggered by $L$. obliqua venom.

In addition, it was observed a great production of the coagulation activation markers prothrombin $\mathrm{F} 1+2$ and thrombin-antithrombin (TAT) complex, which is associated with the generation of thrombin in envenomed patients. Extremely high D-dimer levels were observed in all patients after contact with the caterpillar, indicating disseminated intravascular coagulation. Tissue plasminogen activator (TPA) and plasminogen activator inhibitor-1 (PAl-1) levels did not change substantially, while plasminogen and $\alpha 2$-antiplasmin levels were significantly reduced in cases of afibrinogenemia. Consumption of these fibrinolytic factors, associated with high levels of D-dimer, indicates intense fibrinolysis. These observations altogether indicate a consumptive coagulopathy and secondary fibrinolysis.

\section{Lonomia obliqua BLEEDING SYNDROME AND DIC}

Disseminated intravascular coagulation (DIC) is a syndrome associated with certain clinical conditions (e.g. trauma, neoplasia, sepsis) and is characterized by a systemic activation of the coagulation system and a loss of the hemostatic balance $(45,47$, 51). This syndrome is caused by enhanced and abnormal generation of thrombin (from prothrombin) into circulation, leading to consumption and depletion of clotting and anticlotting factors. Clinical manifestations can vary from bleeding to thrombosis in large and small blood vessels resulting in widespread vascular or microvascular fibrin deposition $(28,31,47)$. Clinical and laboratory parameters for DIC diagnosis were algorithmically defined (46) and involved prolonged clotting time, elevated concentration of fibrin degradation products as well as reduced levels of platelets, coagulation proteins, and inhibitors.

The consumptive coagulopathy associated with lonomism seems to be different from that observed in DIC, since in the former there is no reduction of factors XII, II and X, and the platelet number remains unaltered. In contrast, reduction of factors V, VIII and XIII, and PK levels can be attributed to consumption during coagulation, similarly to that of DIC. An increase in the concentration of F1+2 and TAT complex (as in DIC) was reported after $L$. obliqua envenomation (53). However, values of TAT reaching $900 \mu \mathrm{g} / \mathrm{l}$ were much higher than those observed in patients with other causes of DIC, in which the levels did not exceed $100 \mu \mathrm{g} / \mathrm{l}(9,10,51,52)$. Interestingly, it seems that 
AT is not consumed as it is in other types of DIC $(12,51)$, even though large amounts of thrombin and TAT complex seem to be generated, particularly in patients with a more severe coagulopathy. Therefore, despite the presence of consumptive coagulopathy in $L$. obliqua envenomation, the initiation and maintenance mechanisms of this special form of DIC seems to be different from that observed in other clinical situations. Additional studies are necessary to clarify the pathophysiologic process involved in DIC and the hemorrhagic syndrome common in patients envenomed by the contact with $L$. obliqua bristles.

\section{ANTIVENOM THERAPY}

In Venezuela, conventional therapy with antifibrinolytic drugs such as aprotinin and $\varepsilon^{-}$ aminocaproic acid has been successfully used for treating patients envenomed by $L$. achelous, since the major biological activity of its venom is activation of the fibrinolytic system (8). Also, administration of cryoprecipitate or purified fibrinogen apparently contributes to stop clinical evidence of bleeding (6). In contrast, replacement therapy with either whole blood or fresh-frozen plasma has been shown to exacerbate the clinical symptoms of envenomation $(4,5)$. In Brazil, administration of $\varepsilon$-aminocaproic acid $(17,40)$, blood transfusion, replacement of clotting factors (fibrinogen and cryoprecipitates of factor VIII), and dialytic therapy have been used to reverse clinical manifestations of patients envenomed by $L$. obliqua caterpillar (16). Nevertheless, antifibrinolytics or cryoprecipitates have not been effective (40) and thus are not recommended for $L$. obliqua envenomation. Moreover, as in $L$. achelous envenomation, the administration of whole blood or fresh-frozen plasma is not indicated because they exacerbate DIC (4).

In the last years, Butantan Institute, São Paulo, Brazil, developed an antilonomic serum for specific treatment of envenomation caused by contact with Lonomia obliqua. This antiserum is obtained by immunizing horses with L. obliqua bristle extracts, which triggers the production of specific IgG antibodies $(17,40)$. The antivenom is composed by purified $F\left(a b^{\prime}\right)_{2}$ and was shown to be effective in reverting hemostatic disturbances and bleeding observed in humans and experimental animals envenomed by $L$. obliqua (17). Since the antivenom has been standardized and produced in large scale (40), treatment of envenomed patients is now largely based on its administration. Caovilla and Barros investigated the optimal dose of antilonomic serum for immunotherapy (14). Finally, Zanin and collaborators (53) 
A. M. Chudzinski-Tavassi and L. C. Carrijo-Carvalho BIOCHEMICAL AND BIOLOGICAL PROPERTIES OF Lonomia obliqua BRISTLE EXTRACT. J. Venom. Anim. Toxins incl. Trop. Dis., 2006, 12, 2, p. 161

demonstrated that early diagnosis and an adequate treatment, particularly within the first 12 hours, could prevent severe coagulopathy in a great number of patients. After the introduction of $L$. obliqua antivenom, no more deaths were recorded (40).

\section{EXPERIMENTAL ENVENOMATION}

Laboratory findings about the effects of Lonomia obliqua bristle extracts on animal models are consistent with data on blood coagulation and fibrinolysis in patients. Blood uncoagulability with prolonged clotting time and bleeding time, as well as $\mathrm{Fg}$ depletion, was observed in rats, rabbits and mice and showed to be dose-dependent $(29,35,37,40)$. In addition, Prezoto and collaborators (35) demonstrated that LOCBE is effective in preventing thrombus formation but does not exert thrombolytic activity in pre-formed thrombi. The antithrombotic effect of LOCBE is most probably due to $\mathrm{Fg}$ depletion as a consequence of consumptive coagulopathy. Local and systemic effects of LOCBE and its toxins are summarized in Table 1.

Although experimental envenomation by LOCBE caused complete $\mathrm{Fg}$ depletion, a $50 \%$ decrease of FXIII levels was observed in rats (Table 1). This reduced level of plasma FXIII zymogen in treated rats $(25,35)$ is apparently similar to that observed in humans envenomed by L. obliqua (53). In these cases, FXIII reduction is related to consumption and not to degradation, as indicated by in vitro studies, which showed that FXIII levels were unchanged irrespective of whether they were measured in fibrinogen-depleted plasma of LOCBE-treated or untreated rats (25). Furthermore, the clear correlation between FXIII levels and fibrinogen levels demonstrated by our studies on patients and rats reinforces the theory that decreases in FXIII levels induced by $L$. obliqua are associated with consumptive coagulopathy. It contrasts to what occurs in patients envenomed by $L$. achelous, in which FXIII is drastically reduced due to a factor XIII degradation factor present in the venom (27).

\section{Lonomia obliqua VENOM TOXINS AND BIOCHEMISTRY}

In vitro studies demonstrated that LOCBE induces clot formation by activating the coagulation cascade via both prothrombin and factor $X$ activator activities $(19,29)$. In our laboratory we purified and characterized a prothrombin activator - Lopap (Lonomia obliqua prothrombin activator protease) (39) - and a factor X activator Losac (Lonomia obliqua Stuart-factor activator) (23) - from LOCBE. In addition, some 
other toxins were identified in $L$. obliqua bristle extract by classical biochemical methods (Table 2) and by transcriptomic analysis (50).

Losac purification resulted in a single polypeptide chain of about $43 \mathrm{kDa}$; it was the first factor $X$ activator purified from Lepidopter secretion. This enzyme can activate factor $\mathrm{X}$ in a concentration-dependent manner forming $\mathrm{FXa}$, which integrates the prothrombinase complex (42). An indirect assay was used to evaluate factor $X$ activator activity of Losac, and it was based on the capability of this enzyme to form factor $\mathrm{Xa}$ in the presence of factor $\mathrm{X}$ and a chromogenic substrate specific for factor Xa (S-2222). Losac activity was totally inhibited by phenylmethylsulphonylfluoride (PMSF), indicating that this enzyme is a serine-like protease. Partial amino acid sequencing of Losac showed no similarities with any other well-known factor $X$ activator sequences. The biochemical properties of this newly characterized factor $\mathrm{X}$ activator are still being investigated.

The prothrombin activator named Lopap is the most studied protein concerning $L$. obliqua bristle extract components. Lopap is a $69-\mathrm{kDa}$ tetrameric protein with a prothrombin activator activity independent of the prothrombinase compounds, although calcium ions increase its activity (39). The purified protein activates prothrombin in a dose-dependent manner and its mechanism of action is similar to that of factor Xa, generating thrombin, which is capable of clotting purified fibrinogen. In an indirect assay using a chromogenic substrate specific for thrombin (S-2238) in the presence of prothrombin and calcium, the extract and purified protein presented a prothrombin activator activity similar to that of factor Xa. Lopap activity is inhibited by antilonomic serum (17) and serine protease inhibitors such as PMSF (38, 39). However, amino acid sequencing of Lopap indicated no homology with prothrombin activators or other serine proteases known, but with lipocalins.

Infusion of Lopap into rats causes a coagulopathy similar to the one that occurs in human envenomation (37), indicating that it could be one of the toxins responsible for the severe consumptive coagulopathy found in patients envenomed by $L$. obliqua. Besides its prothrombin activator activity, we have shown that Lopap acts on endothelial cells responses inducing expression of mediators involved in clotting, in inflammation and in the fibrinolytic system, as well as affecting cell viability and mechanisms of anti-apoptosis (15, 24).

In vitro experiments demonstrated that $L$. obliqua venom mainly presents procoagulant activity and is not capable of activating the fibrinolytic system or 
A. M. Chudzinski-Tavassi and L. C. Carrijo-Carvalho BIOCHEMICAL AND BIOLOGICAL PROPERTIES OF Lonomia obliqua BRISTLE EXTRACT. J. Venom. Anim. Toxins incl. Trop. Dis., 2006, 12, 2, p. 163

degrading cross-linked fibrin $(25,29)$. These results agree with in vivo studies reported by Prezoto and collaborators (35), who showed that LOCBE is not capable of lysing pre-formed thrombi.

Some authors showed that $L$. obliqua venom has fibrinogenolytic activity $(25,34,49)$, which hardly occurs with high concentrations of bristles extract and long incubation time with the fibrinogen molecule. Prolongation of the fibrinogen clotting time could be observed at a 1:2 stoichiomethy, an uncommon situation during envenomation. In addition, the products generated are different from those induced by plasmin, and no clot lysis is observed in fibrin plate (25). All data found up until now indicate that fibrinolysis is not caused by L. obliqua venom but seems to be secondary to DIC in the envenomation syndrome.

\section{CONCLUSION}

The data presented here reinforce the idea that the pathogenic mechanisms involved in the hemorrhagic syndrome observed in patients envenomed either by L. obliqua or by $L$. achelous are related to venom proteins that have different specific activities in each species. While in envenomation by $L$. achelous hemorrhage is due to enzymes that degrade FXIII and proteins that activate fibrinolysis, in envenomation by $L$. obliqua bleeding manifestations seem to be related to a consumptive coagulopathy induced by the presence of procoagulant proteins. Therefore, therapy should be conducted according to the main mechanism involved in each case. Antifibrinolytic agents are not recommended for $L$. obliqua accidents and the treatment should be based on the administration of antivenom, which is an effective way to reverse hemostatic disturbances and bleeding. 
A. M. Chudzinski-Tavassi and L. C. Carrijo-Carvalho BIOCHEMICAL AND BIOLOGICAL PROPERTIES OF Lonomia obliqua BRISTLE EXTRACT. J. Venom. Anim. Toxins incl. Trop. Dis., 2006, 12, 2, p. 164

Table 1: In vivo effects of Lonomia obliqua bristle extract.

\begin{tabular}{|c|c|c|c|c|}
\hline Effect observed & $\begin{array}{c}\text { Animal } \\
\text { model }\end{array}$ & $\begin{array}{l}\text { Venom } \\
\text { fraction }\end{array}$ & Observations & References \\
\hline \multirow{2}{*}{$\begin{array}{c}\text { Blood incoagulability with } \\
\text { prolonged clotting time (PT } \\
\text { and APTT) and bleeding } \\
\text { time; fibrinogen and FXIII } \\
\text { depletion }\end{array}$} & $\begin{array}{l}\text { rat, rabbit } \\
\text { and mouse }\end{array}$ & LOCBE & Dose-dependent effect & $25,35,40$ \\
\hline & $\begin{array}{l}\text { mouse and } \\
\text { rat }\end{array}$ & Lopap & $\begin{array}{l}\text { DIC in the rat cremaster } \\
\text { microcirculatory network (observed } \\
\text { by intravital microscopy) }\end{array}$ & 37,38 \\
\hline Antithrombotic effect & $\begin{array}{l}\text { rabbit and } \\
\text { rat }\end{array}$ & LOCBE & $\begin{array}{c}\text { Prevention of thrombus formation, } \\
\text { and incapability of inducing lysis of } \\
\text { preformed thrombi }\end{array}$ & 35 \\
\hline Lethality & mouse & LOCBE & $\begin{array}{l}\mathrm{LD}_{50}=0.19 \mathrm{mg} \mathrm{IV} / 18-20 \mathrm{~g} \text { mouse; } \\
\text { no death was observed with up to } \\
1 \mathrm{mg} \text { IP } / 18-20 \mathrm{~g} \text { mouse. }\end{array}$ & 40 \\
\hline $\begin{array}{l}\text { Acute inflammatory } \\
\text { reaction }\end{array}$ & mouse & LOCBE & $\begin{array}{l}\text { Effect observed in genetically } \\
\text { selected lines of mice }\end{array}$ & 36 \\
\hline Intravascular hemolysis & rat & LOCBE & $\begin{array}{c}\text { Intravascular hemolysis has not } \\
\text { been reported in humans after } \\
\text { accidental contact with Lonomia } \\
\text { obliqua }\end{array}$ & 41 \\
\hline $\begin{array}{c}\text { Edematogenic and } \\
\text { nociceptive responses }\end{array}$ & rat & LOCBE & $\begin{array}{l}\text { Nociception is inhibited by } \\
\text { indomethacin pretreatment and } \\
\text { seems to be facilitated by } \\
\text { prostaglandin production; edema is } \\
\text { reduced by loratadine pretreatment } \\
\text { and is probably mediated by } \\
\text { prostanoids and histamine }\end{array}$ & 11 \\
\hline $\begin{array}{l}\text { Damage in the central } \\
\text { nervous system, causing } \\
\text { disruption of the blood } \\
\text { brain barrier }\end{array}$ & rat & LOCBE & $\begin{array}{l}\text { Intracerebral hemorrhage was } \\
\text { rarely observed, occurring } 24 \mathrm{~h} \\
\text { after envenomation }\end{array}$ & 43 \\
\hline
\end{tabular}

LOCBE: Lonomia obliqua bristle extract

Lopap: Lonomia obliqua prothrombin activator protease

PT: Prothrombin time

APTT: Activated partial thromboplastin time

DIC: Disseminated intravascular coagulation 
A. M. Chudzinski-Tavassi and L. C. Carrijo-Carvalho BIOCHEMICAL AND BIOLOGICAL PROPERTIES OF Lonomia obliqua BRISTLE EXTRACT. J. Venom. Anim. Toxins incl. Trop. Dis., 2006, 12, 2, p. 165

Table 2: In vitro activities identified in Lonomia obliqua bristle extract.

\begin{tabular}{|c|c|c|c|}
\hline Activity & $\begin{array}{c}\text { Toxin } \\
\text { Molecular Weight } \\
\text { (Da) }\end{array}$ & Characteristic & References \\
\hline Prothrombin activator & $\begin{array}{l}\text { Lopap } \\
69,000 \\
\text { (tetrameric) }\end{array}$ & $\begin{array}{c}\text { Serine protease } \\
\mathrm{Ca}^{2+} \text { increases its activity }\end{array}$ & 19,39 \\
\hline Factor Xa-like & 20,746 & $\begin{array}{l}\text { Amino acid sequence shows } \\
\text { 100\% homology with the } \\
\text { Lopap sequence [gi: } \\
\text { 59709575] deposited in the } \\
\text { National Center for } \\
\text { Biotechnology Information } \\
\text { (NCBI) data bank }\end{array}$ & 32 \\
\hline Factor $\mathrm{X}$ activator & $\begin{array}{l}\text { Losac } \\
43,000\end{array}$ & $\begin{array}{l}\text { Serine protease } \\
\mathrm{Ca}^{2+} \text {-independent }\end{array}$ & 19,23 \\
\hline Phospholipase $\mathrm{A}_{2}$-like & 15,000 & $\begin{array}{c}\text { Indirect hemolytic activity in } \\
\text { human and rats red blood } \\
\text { cells }\end{array}$ & 42 \\
\hline$\alpha \beta$-Fibrinogenase-like & $\begin{array}{l}\text { Lonofibrase } \\
35,000\end{array}$ & $\begin{array}{l}\text { Incapable of inducing fibrin } \\
\text { clot lysis }\end{array}$ & $25,34,49$ \\
\hline Hyaluronidase-like & $\begin{array}{l}49,000 \\
53,000\end{array}$ & $\begin{array}{c}\text { They display hydrolase } \\
\text { activity as a } \beta \text { - } \\
\text { endohexosaminidase; } \\
\text { degradation of purified } \\
\text { hyaluronic acid, purified } \\
\text { chondroitin sulphate, and } \\
\text { extracellular matrix }\end{array}$ & 26 \\
\hline Anti-apoptotic ${ }^{*}$ & 51,000 & $\begin{array}{c}\text { Activity on Spodoptera } \\
\text { frugiperda (Sf-9) cell culture }\end{array}$ & 44 \\
\hline
\end{tabular}

* Identified in L. obliqua hemolymph.

Lopap: Lonomia obliqua prothrombin activator protease.

Losac: Lonomia obliqua Stuart-factor activator. 


\section{REFERENCES}

1 ALVARENGA Z. A taturana. In: CONGRESSO BRASILEIRO DE MEDICINA E CIRURGIA, 8, Belo Horizonte, 1912. Anais... V.2. p.132-5.

2 AROCHA-PIÑANGO CL. Fibrinolisis producida por contato com orugas: comunicación preliminar. Acta Cient. Venez., 1967, 18, 136-9.

3 AROCHA-PIÑANGO CL., BLUMENFELD-BOSCH N., NOUEL AL., TORRES A., PERALES J., ALONSO ME., RODRIGUEZ S., CARVAJAL AZA., OJEDA A., TASAYCO ML., CHITTY W. Fibrinolytic and procoagulant agents from a Saturniidae moth caterpillar. In: PIRKLE H., MARKLAND FS. Eds. Haemostasis and animal venoms. New York: Marcel Dekker, 1988: 223-40.

4 AROCHA-PIÑANGO CL., DE BOSCH NB., TORRES A., GOLDSTEIN C., NOUEL A., ARGUEllo A., CARVAJAL Z., GUERRERO B., OJEDA A., RODRIGUEZ A., RODRIGUEZ S. Six new cases of caterpillar-induced bleeding syndrome. Thromb. Haemost., 1992, 67, 402-7.

5 AROCHA-PIÑANGO CL., GUERRERO B. Lonomia genus caterpillar envenomation: clinical and biological aspects. Haemostasis, 2001, 31, 288-93.

6 AROCHA-PIÑANGO CL., GUERRERO B. Hemorrhagic syndrome induced by caterpilars. Clinical and experimental studies. Review. Invest. Clin., 2003, 44, 155-63.

7 AROCHA-PIÑANGO CL., LAYRISSE M. Fibrinolysis produced by contact with a caterpillar. Lancet, 1969, 1, 810-2.

8 AROCHA-PIÑANGO CL., MARVAL E., GUERRERO B. Lonomia genus caterpillar toxins: biochemical aspects. Biochimie, 2000, 82, 937-42.

9 ASAKURA H., ONTACHI Y., MIZUTANI T., KATO M., ITO T., SAITO M., MORISHITA E., YAMASAKI M., AOSHIMA K., TAKAMI A., YOSHIDA T., SUGA Y., MIYAMOTO K., NAKAO S. Decreased plasma activity of antithrombin or protein $C$ is not due to consumption coagulopathy in septic patients with disseminated intravascular coagulation. Eur. J. Haematol., 2001, 67, 170-5.

10 ASAKURA $H_{\text {., }}$ SHIRATORI Y., JOKAJI H., SAITO M., UOTANI C., KUMABASHIRI I., MORISHITA E., YAMAZAKI M., MATSUDA T. Changes in plasma levels of prothrombin fragment $\mathrm{F} 1+2$ in cases of disseminated intravascular coagulation. Acta Haematol., 1993, 89, 22-5. 
11 BASTOS LC., VEIGA ABG., GUIMARÃES JA., TONUSSI CR. Nociceptive and edematogenic responses elicited by a crude bristle extract of Lonomia obliqua caterpillars. Toxicon, 2004, 43, 273-8.

12 BAUDO F., CAIMI TM., DE CATALDO F., RAVIZZA A., ARLATI A., CASELLA G., CARUGO D., PALARETI G., LEGNANI C., RIDOLFI L., ROSSI R., D'ANGELO A., CRIPPA L., GIUDICI D., GALLIOLI G., WOLFLER A., CALORI G. Antithrombin III replacement therapy in patients with sepsis and/or post surgical complication: a double-bind, randomized, multicenter study. Intensive Care Med., 1998, 24, 336-42.

13 BURDMANN EA., ANTUNES I., SALDANHA LB., ABDULKADER RC. Severe acute renal failure induced by the venom of Lonomia caterpillars. Clin. Nephrol., 1996, 46, 337-9.

14 CAOVILLA JJ., BARROS EJ. Efficacy of two different doses of antilonomic serum in the resolution of hemorrhagic syndrome resulting form envenoming by Lonomia obliqua caterpillars: a randomized controlled trial. Toxicon, 2004, 43, 811-8.

15 CHUDZINSKI-TAVASSI AM., SCHATTNER M., FRITZEN M., POZNER RG., REIS CV., LOURENÇO D., LAZZARI MA. Effects of lopap on human endothelial cells and platelets. Haemostasis, 2001, 31, 257-65.

16 CORRÊA MS., SIQUEIRA-BATISTA R., GOMES AP., FRANCO-BARBOSA A., VERZOLA ACA., OLIVEIRA FRQ., SQUEFF FA., MOTTA-LEAL-FILHO JM., TAVARES RQ., DE AMORIM DS., DE-MARIA-MOREIRA NL., SANTOS SS. Erucismo por Lonomia spp em Teresópolis, RJ, Brasil. Relato de um caso provável e revisão da literatura. Rev. Soc. Bras. Med. Trop., 2004, 37, 418-21.

17 DA SILVA WD., CAMPOS CM., GONÇALVES LR., SOUZA-E-SILVA MC., HIGASHI HG., YAMAGUSHI IK., KELEN EM. Development of an antivenom against toxins of Lonomia obliqua caterpillars. Toxicon, 1996, 34, 1045-9.

18 DIAZ JH. The evolving global epidemiology, syndromic classification, management, and prevention of caterpillar envenoming. Am. J. Trop. Med. Hyg., 2005, 72, 347-57.

19 DONATO JL., MORENO RA., HYSLOP S., DUARTE A., ANTUNES E., LE BONNIEC BF., RENDU F., DE NUCCI G. Lonomia obliqua caterpillar spicules trigger human blood coagulation via activation of factor $\mathrm{X}$ and prothrombin. Thromb. Haemost., 1998, 79, 539-42. 
20 DUARTE AC., CAOVILLA J., LORINI I., LORINI D., MANTOVANI G., SUMIDA J., MANFRE PC., SILVEIRA RC., DE MOURA SP. Insuficiência renal aguda por acidentes com lagartas. J. Bras. Nefrol., 1990, 12, 184-7.

21 DUARTE AC., CRUSIUS PS., PIRES CA., SCHILLING MA., FAN HW. Intracerebral haemorrhage after contact with Lonomia caterpillars. Lancet, 1996, 348, 1033.

22 FAN HW., CARDOSO JLC., OLMOS RD., ALMEIDA FJ., VIANA RP., MARTINEZ APP. Hemorrhagic syndrome and acute renal failure in a pregnant woman after contact with Lonomia caterpillars: a case report. Rev. Inst. Med. Trop. São Paulo, 1998, 40, 119-20.

23 FLORES MPA., FRITZEN M., CHUDZINSKI-TAVASSI AM. Effects of Losac (a factor $\mathrm{X}$ activator from Lonomia obliqua caterpillar) on HUVECs and sequencing. In: CONGRESSO DA SOCIEDADE BRASILEIRA DE TOXINOLOGIA, 8, Angra dos Reis, 2004. Abstracts... J. Venom. Anim. Toxins incl. Trop. Dis., 2004, 10, 532.

24 FRITZEN M., FLORES MP., REIS CV., CHUDZINSKI-TAVASSI AM. A prothrombin activator (Lopap) modulating inflamation, coagulation and cell survival mechanisms. Biochem. Biophys. Res. Commun., 2005, 333, 517-23.

25 FRITZEN M., SCHATTNER M., RIBEIRO AL., BATISTA IF., VENTURA J., PREZOTO BC., CHUDZINSKI-TAVASSI AM. Lonomia obliqua venom action on fibrinolytic system. Thromb. Res., 2003, 112, 105-10.

26 GOUVEIA AICB., DA SILVEIRA RB., NADER HB., DIETRICH CP., GREMSKI W., VEIGA SS. Identification and partial characterization of hyaluronidases in Lonomia obliqua venom. Toxicon, 2005, 45, 403-410.

27 GUERRERO BA., AROCHA-PIÑANGO CL., GIL SAN JUAN A. Degradation of human factor XIII by lonomin V, a purified fraction of Lonomia achelous caterpillar venom. Thromb. Res., 1997, 87, 171-81.

28 HAMBLETON J., LEUNG LL., LEVI M. Coagulation: consultative hemostasis. Hematology (Am. Soc. Hematol. Educ. Program), 2002, 335-52.

29 KELEN EMA., PICARELLI ZP., DUARTE AC. Hemorrhagic syndrome induced by contact with caterpillars of the genus Lonomia (Saturniidae, Hemileucinae). J. Toxicol. Toxin Rev., 1995, 14, 283-308.

30 LEMAIRE C. Révision du genre Lonomia Walker (Lep Attacidae). Ann. Soc. Entomol. Fr., 1972, 8, 767-861. 
31 LEVI M., DE JONGE E., MEIJERS J. The diagnosis of disseminated intravascular coagulation. Blood Rev., 2002, 16, 217-23.

32 LILLA S., PEREIRA R., HYSLOP S., DONATO JL., LE BONNIEC BF., NUCCI G. Purification and initial characterization of a novel protein with factor Xa activity from Lonomia obliqua caterpillar spicules. J. Mass Spectrom., 2005, 40, 40512.

33 LORINI LM., CORSEUIL E. Aspectos morfológicos de Lonomia obliqua Walker (Lepidoptera: Saturniidae). Neotrop. Entomol., 2001, 30, 373-8.

34 PINTO AFM., DOBROVOLSKI R., VEIGA ABG., GUIMARÃES JA. Lonofibrase, a novel alpha-fibrinogenase from Lonomia obliqua caterpillars. Thromb. Res., 2004, 113, 147-54.

35 PREZOTO BC., MAFFEI FH., MATTAR L., CHUDZINSKI-TAVASSI AM., CURI PR. Antithrombotic effect of Lonomia obliqua caterpillar bristle extract on experimental venous thrombosis. Braz. J. Med. Biol. Res., 2002, 35, 703-12.

36 RAMOS AT., GONÇALVES LRC., RIBEIRO OG., CAMPOS ACR., SANT'ANNA OA. Effects of Lonomia obliqua (Lepidoptera, Saturniidae) toxin on clotting, inflammatory and antibody responsiveness in genetically selected lines of mice. Toxicon, 2004, 43, 761-8.

37 REIS CV., FARSKY SH., FERNANDEZ BL., SANTORO ML., OLIVA ML., MARIANO M., CHUDZINSKI-TAVASSI AM. In vivo characterization of Lopap, a prothrombin activator serine protease from the Lonomia obliqua caterpillar venom. Thromb. Res., 2001, 102, 437-43.

38 REIS CV., KELEN EM., FARSKY SH., PORTARO FC., SAMPAIO CA., FERNANDES BL., CAMARGO AC., CHUDZINSKI-TAVASSI AM. A $\mathrm{Ca}^{++}$ activated serine protease (LOPAP) could be responsible for the haemorrhagic syndrome caused by the caterpillar Lonomia obliqua. L. obliqua prothrombin activator protease. Lancet, 1999, 353, 1942.

39 REIS CV., PORTARO FC., ANDRADE SA., FRITZEN M., FERNANDEZ BL., SAMPAIO CA., CAMARGO AC., CHUDZINSKI-TAVASSI AM. A prothrombin activator serine protease from the Lonomia obliqua caterpillar venom (Lopap) biochemical characterization. Thromb. Res., 2001, 102, 427-36. 
40 ROCHA-CAMPOS AC., GONÇALVES LR., HIGASHI HG., YAMAGUSHI IK., FERNANDEZ I., OLIVEIRA JE., RIBELA MT., SOUSA-E-SILVA MC., DA SILVA WD. Specific heterologous $F\left(a b^{\prime}\right)_{2}$ antibodies revert blood incoagulability resulting from envenoming by Lonomia obliqua caterpillars. Am. J. Trop. Med. Hyg., 2001, 64, 283-9.

41 SEIBERT CS., OLIVEIRA MR., GONÇALVES LR., SANTORO ML., SANOMARTINS IS. Intravascular hemolysis induced by Lonomia obliqua caterpillar bristle extract: an experimental model of envenomation in rats. Toxicon, 2004, 44, 793-9.

42 SEIBERT CS., SHINOHARA EM., SANO-MARTINS IS. In vitro hemolytic activity of Lonomia obliqua caterpillar bristle extract on human and wistar rat erythrocytes. Toxicon, 2003, 41, 831-9.

43 SILVA GH., HYSLOP S., CRUZ-HÖFLING MA. Lonomia obliqua caterpillar venom increases permeability of the blood-brain barrier in rats. Toxicon, 2004, 44, 625-34.

44 SOUZA APB., PEIXOTO CC., MARANGA L., CARVALHAL AV., MORAES RHP., MENDONÇA RZM., PEREIRA CA., CARRONDO MJT., MENDONÇA RZ. Purification and characterization of an anti-apoptotic protein isolated from Lonomia obliqua hemolymph. Biotechnol. Prog., 2005, 21, 99-105.

45 SPERO JA., LEWIS JH., HASIBA U. Disseminated intravascular coagulation. Findings in 346 patients. Thromb. Haemost., 1980, 43, 28-33.

46 TAYLOR Jr. FB., TOH CH., HOOTS WK., WADA H., LEVI M.; Scientific Subcommittee on Disseminated Intravascular Coagulation (DIC) of the International Society on Thrombosis and Haemostasis (ISTH). Towards definition, clinical and laboratory criteria, and a scoring system for disseminated intravascular coagulation. Thromb. Haemost., 2001, 86, 102730.

47 TOH CH., DENNIS M. Disseminated intravascular coagulation: old disease, new hope. Br. Med. J., 2003, 327, 974-7.

48 VEIGA AB., BLOCHTEIN B., GUIMARÃES JA. Structures involved in production, secretion and injection of the venom produced by the caterpillar Lonomia obliqua (Lepidoptera, Saturniidae). Toxicon, 2001, 39, 1343-51. 
49 VEIGA AB., PINTO AF., GUIMARÃES JA. Fibrinogenolytic and procoagulant activities in the hemorrhagic syndrome caused by Lonomia obliqua caterpillars. Thromb. Res., 2003, 111, 95-101.

50 VEIGA AB., RIBEIRO JM., GUIMARÃES JA., FRANCISCHETTI IM. A catalog for the transcripts from the venomous structures of the caterpillar Lonomia obliqua: Identification of the proteins potentially involved in the coagulation disorder and hemorrhagic syndrome. Gene, 2005, 355, 11-27.

51 WADA H., SAKURAGAWA N., MORI Y., TAKAGI M., NAKASAKI T., SHIMURA M., HIYOYAMA K., NISIKAWA M., GABAZZA EC., DEGUCHI K., KAZAMA M., SHIKU H. Hemostatic molecular markers before the onset of disseminated intravascular coagulation. Am. J. Hematol., 1999, 60, 273-8.

52 WADA H., WAKITA Y., NAKASE T., SHIMURA M., HIYOYAMA K., NAGAYA S., MORI Y., SHIKU H. Outcome of disseminated intravascular coagulation in relation to the score when treatment was begun. Mie DIC Study Group. Thromb. Haemost., 1995, 74, 848-52.

53 ZANNIN M., LOURENÇO DM., MOTTA G., DALLA COSTA LR., GRANDO M., GAMBORGI GP., NOGUTI MA., CHUDZINSKI-TAVASSI AM. Blood coagulation and fibrinolytic factors in 105 patients with hemorrhagic syndrome caused by accidental contact with Lonomia obliqua caterpillar in Santa Catarina, southern Brazil. Thromb. Haemost., 2003, 89, 355-64. 